\title{
PENERAPAN PEMBELAJARAN BERBASIS APLIKASI TWITTER \\ DALAM MENINGKATKAN KETERAMPILAN MENULIS DAN \\ MEMBACA CERITA PENDEK
}

\author{
Novi Roza Primadhani \\ E-mail: noviroza@gmail.com \\ Program Studi Pendidikan Bahasa dan Sastra Indonesia, Universitas Riau
}

\section{Pengantar}

Perkembangan ilmu pengetahuan dan teknologi berhasil memberikan perubahan yang signifikan dalam berbagai dimensi kehidupan manusia. Perubahan yang disebabkan oleh perkembangan IPTEK ini juga ikut mempengaruhi kualitas sumber daya manusia. Kualitas sumber daya manusia merupakan hal yang menjadi eksistensi utama dari suatu bangsa. Tolak ukur utama dari kualitas sumber daya manusia dapat dinilai dari bagaimana keadaan dimensi pendidikan pada bangsa itu sendiri. Apabila mutu pendidikan pada suatu bangsa sudah baik, maka dapat dikatakan kualitas sumber daya manusia yang dimiliki sudah baik. Namun sebaliknya, apabila mutu pendidikan pada suatu bangsa rendah, maka orang akan menilai kualitas sumber daya manusia yang dimiliki juga rendah.

Seiring dengan perkembangan zaman, pendidikan juga harus ikut dibenahi agar dapat mengikuti dan menyesuaikan dengan kebutuhan. Hal ini dikarenakan pendidikan merupakan salah satu usaha untuk membina, mengembangkan, dan membentuk karakter manusia, baik rohani maupun jasmani. Salah satu upaya agar pendidikan tetap dapat mengikuti perkembangan dunia adalah dengan melakukan inovasi. (Simarmata, 2019 \& Mawati, 2020) menjelaskan bahwa inovasi pendidikan harus dilakukan agar pendidikan yang selalu adaptif dengan perubahan-perubahan dan perkembangan zaman serta tidak akan terjadi kesenjangan antara realitas dan idealitas. Selain itu, dengan adanya inovasi pendidikan juga diharapkan mampu untuk meningkatkan mutu pembelajaran di lingkungan sekolah. 
Menurut undang-undang Sistem Pendidikan Nasional No. 20 Tahun 2003, Pembelajaran didefinisikan sebagai proses interaksi peserta didik dengan pendidik dan sumber belajar pada suatu lingkungan belajar. Pembelajaran merupakan proses transfer ilmu pengetahun dari tenaga pendidik ke peserta didik dengan memanfaatkan sumber-sumber belajar untuk tercapainya tujuan pembelajaran yang ingin dicapai. Berdasarkan penjelasan tersebut dapat dipahami bahwa sumber-sumber atau media yang digunakan dalam proses pembelajaran sangat berpengaruh terhadap ketercapaian tujuan pembelajaran.

(Furnhan dkk., 2005) dalam (Mustafa, M. N., Hermandra, \& Zulhafizh, 2019) explain that by using media, students feel more interactive and tend to be more academically successful. It is believed that instructionally, the use of media makes a teacher easier to convey commands and information for learning to his students. Artinya, dengan adanya penggunaan media mampu membuat peserta didik untuk lebih interaktif dan cenderung berhasil secara akademis. Kemudian, dengan adanya penggunaan media dalam proses pembelajaran membuat tenaga pendidik lebih mudah untuk menyampaikan informasi-informasi terkait pembelajaran kepada peserta didik.

Penggunaan teknologi informasi khususnya media sosial memang dapat memberikan dampak positif sekaligus mempermudah tenaga pendidik maupun peserta didik dalam mengakses berbagai hal terkait pembelajaran. Cakupan penggunaan media sosial yang tidak terbatas dapat dimanfaatkan untuk berbagai hal, meliputi sarana informasi dan komunikasi, sarana pembelajaran, dan sebagainya. Berdasarkan permasalahan tersebut, penulis meyakini bahwa model pembelajaran yang dapat diterapkan dan cukup efektif digunakan saat ini adalah pembelajaran berbasis aplikasi. Salah satu sumber atau media yang dapat dimanfaatkan untuk pembelajaran berbasis aplikasi adalah aplikasi twitter. Hal ini dikarenakan twitter merupakan salah satu aplikasi yang banyak digunakan, terkhusus di kalangan muda. 
Twitter merupakan salah satu aplikasi yang cukup popular pada saat ini. Twitter sendiri didirikan pada Maret 2006 oleh Jack Dorsey, Evan Williams dan Biz Stone. (Warouw Bandjar dan Marentek, 2019) dalam (Samsir dkk., 2021) menjelaskan bahwa konsep awal twitter adalah sebuah sistem yang bisa membantu para penggunanya untuk dapat mengirimkan pesan yang dapat disebarkan ke semua teman, rekan, dan kerabat serta keluarga mereka. Berbeda dengan konsep sebelumnya, saat ini aplikasi twitter memiliki berbagai fitur yang dapat dimanfaatkan dalam pembelajaran. Dengan memanfaatkan fiturfitur seperti spaces, threads, dan unggahan video dalam twitter diharapkan dapat untuk meningkatkan keterampilan menulis dan membaca peserta didik, terutama pada materi menulis dan membaca cerita pendek atau cerpen.

\section{Tindakan yang Dilakukan}

Pembelajaran berbasis aplikasi twitter memang diharapkan mampu untuk meningkatkan keterampilan menulis dan membaca cerpen peserta didik. Dalam penerapannya, ada beberapa tindakan yang harus dilakukan agar pembelajaran dapat berjalan dengan sebagaimana mestinya. Berdasarkan hal tersebut, tenaga pendidik harus mengetahui dan memahami fitur-fitur yang dapat dimanfaatkan dalam aplikasi twitter. Adapun fitur-fitur yang terdapat dalam aplikasi twitter adalah sebagai berikut:

\section{a. Spaces}

Spaces merupakan salah satu fitur yang dapat digunakan untuk melakukan percakapan audio langsung di twitter. Pengguna twitter bisa saling berinteraksi atau berbicara langsung tentang berbagai topik dan siapapun bisa bergabung untuk mendengarkan topik pembicaraan. Selain itu, pendengar juga bisa meminta kepada host untuk menjadi pembicara ketika spaces sedang berlangsung. Tidak hanya itu, pendengar juga bisa memberikan tanggapan berbentuk angka 100 apabila menyetujui pendapat yang disampaikan oleh pembicara. Berdasarkan hal tersebut, spaces dapat digunakan sebagai media untuk meningkatkan keterampilan membaca cerpen peserta didik. Melalui 
spaces, seluruh pengguna twitter bisa mendengarkan pembacaan cerpen secara langsung meskipun bukan dari pengikut akun tersebut.

\section{b. Threads (Utas)}

Sebagai salah satu media sosial penyedia layanan microblog, maka twitter memberikan fasilitas penulisan pesan yang hanya dapat menampung 140 karakter (Zarrella, 2010:31). Namun pada saat ini, twitter telah menyediakan fitur berupa threads atau biasa disebut dengan utas. Istilah threads atau utas merupakan salah satu bentuk tweet atau status yang ditulis secara menyambung yang menjadi sebuah rangkaian. Dengan adanya threads, pengguna twitter dapat menulis berbagai hal tanpa batas. Selain itu, tulisan dari tweet atau cuitan status tadi dapat di re-tweet atau diunggah ulang oleh pengguna lain tanpa menghilangkan nama dari penulis.

Dengan adanya threads atau utas ini dapat membuat peserta didik menulis berbagai hal, terkhusus cerita pendek secara bebas di twitter. Selain itu, peserta didik juga dapat untuk menuliskan cerita berdasarkan bagian demi bagian cerita yang ingin ditulis sehingga menambah euforia dari tulisan. Semakin banyak pengguna yang mengunggah ulang tulisan tersebut, maka threads tersebut memiliki kemungkinan besar untuk menjadi topik pembicaraan atau trending topic. Jika dilihat dari berbagai aspek, tentunya hal ini sangat menguntungkan sebab dapat meningkatkan eksistensi pembelajaran, terutama dalam pembelajaran menulis cerita pendek.

\section{c. Unggahan Video}

Tidak hanya spaces dan threads, twitter juga memiliki video unggahan seperti aplikasi-aplikasi yang sejenis. Perbedaan antara unggahan video twitter dengan aplikasi lain, twitter dapat menyebarluaskan unggahan video tersebut dalam waktu yang relatif lebih cepat. Apalagi jika ketika mengunggah video, pengguna twitter dapat menambahkan tagar-tagar tertentu sehingga semakin mudah diakses oleh pengguna lain. Dengan adanya unggahan video twitter, tenaga pendidik dapat meminta peserta didik untuk membacakan cerita pendek secara langsung sehingga tenaga pendidik dapat melihat bagaimana ekspresi dan gestur peserta didik ketika membacakan cerita pendek. 
Berdasarkan penjelasan tentang fitur-fitur twitter yang dapat dimanfaatkan untuk meningkatkan keterampilan menulis dan membaca cerita pendek peserta didik di atas, tenaga pendidik dan peserta didik terlebih dahulu harus mempersiapkan hal-hal berikut:

1. Kesiapan tenaga pendidik dan peserta didik.

2. Tenaga pendidik mempelajari dan memahami tentang penggunaan twitter dan menyusun konsep pembelajaran dengan matang.

3. Tenaga pendidik menjelaskan konsep pembelajaran menggunakan aplikasi twitter kepada peserta didik secara langsung atau melalui media (daring) seperti google meeting atau zoom meeting.

4. Melakukan tanya-jawab atau briefing terkait inovasi pembelajaran menggunakan aplikasi twitter.

5. Tenaga pendidik memberikan contoh pengaplikasian dan melakukan simulasi terkait pembelajaran menulis dan membaca cerita pendek di twitter kepada peserta didik secara langsung atau membuat tutorial melalui aplikasi youtube.

6. Memberikan ruang untuk peserta didik dalam mengembangkan atau menginovasikan akun twitter pribadi.

(Mustafa, M. N., Hermandra, \& Zulhafizh, 2019), both teachers and students must work together in solving problems that occur in learning activities. Artinya, antara tenaga pendidik dan peserta didik harus bekerja sama untuk mengatasi berbagai persoalan yang muncul selama proses pembelajaran berlangsung. Kerja sama ini bertujuan untuk mewujudkan penerapan pembelajaran berbasis aplikasi twitter yang efektif. Apabila tenaga pendidik dan peserta didik mampu untuk bekerja sama dengan baik dan saling membantu untuk mengatasi berbagai permasalahan-permasalahan yang muncul dalam pembelajaran, maka dapat dipastikan pembelajaran akan berjalan dengan lancar. 


\section{Sarana Pendukung}

Menurut Ary. H. Gunawan, (1996:14) dalam bukunya yang berjudul Administrasi Sekolah tentang Manajemen Sarana Prasarana bahwasannya Proses Belajar Mengajar (PBM) atau Kegiatan Belajar Mengajar (KBM) akan semakin sukses apabila ditunjang dengan sarana dan prasarana pendidikan yang memadai. Sarana dan prasarana yang digunakan dalam proses pembelajaran tentu harus mampu untuk membuat kegiatan belajar menjadi lebih efektif dan efisien sekaligus dapat menciptakan pembelajaran yang aktif, kreatif, dan menyenangkan. Dengan adanya sarana yang mampu menciptakan suasana belajar yang menarik, maka juga dapat meningkatkan minat belajar peserta didik.

Sarana pendukung yang diperlukan dalam penerapan pembelajaran berbasis aplikasi twitter adalah telepon genggam (handphone) atau laptop. Handphone atau laptop merupakan sarana yang sangat diperlukan untuk membantu kelancaran pembelajaran. Hal ini dikarenakan handphone atau laptop berguna untuk pemasangan aplikasi twitter. Apabila handphone atau laptop tidak ada, maka tenaga pendidik dan peserta didik tidak akan dapat mengunduh dan mengakses aplikasi twitter. Selain itu, handphone atau laptop nantinya juga akan digunakan untuk mengunduh aplikasi pendukung lain seperti whatsapp, telegram, google meet, zoom meeting, google classroom, youtube, dan sejenisnya. Aplikasiaplikasi tersebut akan membantu tenaga pendidik dan peserta didik untuk berinteraksi atau berkomunikasi. Agar dapat mengakses berbagai aplikasi pendukung di atas, tentu juga diperlukan peranan jaringan yang stabil. Jaringan yang lancar dan stabil dapat mempermudah tenaga pendidik dan peserta didik untuk menggunakan aplikasi-aplikasi pendukung dalam pembelajaran.

Selain itu, sarana pendukung lain yang dapat digunakan untuk membantu pelaksanaan penerapan pembelajaran berbasis aplikasi twitter ini adalah berbagai referensi seperti e-book, jurnal, artikel, dan sejenisnya yang memuat infomasi terkait keterampilan menulis dan membaca cerita pendek. Berbagai referensi tersebut dapat dijadikan sebagai rujukan dalam pembelajaran sehingga dapat menambah pengetahuan tenaga pendidik maupun peserta didik. Apabila referensi 
yang dijadikan sebagai rujukan digunakan sebaik mungkin, maka baik tenaga pendidik maupun peserta didik akan lebih mudah untuk memahami hal-hal yang berkaitan dengan keterampilan menulis dan membaca cerita pendek. Semakin paham tenaga pendidik dan peserta didik terhadap pembelajaran tersebut, maka penerapan pembelajaran berbasis aplikasi twitter untuk meningkatkan keterampilan menulis dan membaca cerita pendek akan semakin mudah untuk direalisasikan.

\section{Tindakan Solutif}

Berbagai permasalahan-permasalahan yang tidak terduga memang sering muncul ketika proses pembelajaran berlangsung. Permasalahan-permasalahan tersebut tentu dapat mempengaruhi sikap belajar peserta didik. Padahal sikap belajar siswa turut memengaruhi intensitas pencapaian hasil belajar siswa. Meningkatnya sikap dan motivasi belajar siswa pada aktivitas belajar sangat diharapkan agar hasil belajar siswa juga meningkat (Zulhafizh, Atmazaki \& Syahrul R, 2013). Agar hasil belajar peserta didik tidak terganggu, perlu dilakukan tindakan untuk mengatasi berbagai permasalahan-permasalahan yang terjadi selama aktivitas belajar berlangsung.

Sarana pendukung yang digunakan dalam penerapan pembelajaran berbasis aplikasi twitter adalah handphone atau laptop. Apabila handphone atau laptop pribadi tenaga pendidik atau peserta didik bermasalah, maka dapat menggunakan handphone atau laptop milik keluarga atau teman. Selain itu, tenaga pendidik atau peserta didik juga dapat mengunjungi warung internet (warnet) jika diperlukan. Dengan menggunakan handphone atau laptop orang lain atau mengunjungi warung internet, tenaga pendidik dan peserta didik tetap dapat berkomunikasi dan mengakses aplikasi twitter atau aplikasi-aplikasi pendukung lainnya.

Selanjutnya, apabila tenaga pendidik atau peserta didik kurang paham terkait bagaimana meningkatkan keterampilan menulis dan membaca cerita pendek dengan menggunakan aplikasi twitter, maka dapat mencari dan membaca 
berbagai referensi seperti e-book, jurnal, artikel dan sejenisnya. Jika dalam mengakses referensi tersebut tenaga pendidik dan peserta didik terkendala, maka dapat mengunduh file dan menyimpan secara offline, sehingga lebih mudah untuk dibaca. Namun, apabila masih tetap terkendala, maka tenaga pendidik atau peserta didik dapat mencari buku-buku yang berisi informasi terkait keterampilan menulis dan membaca cerita pendek. Apabila tenaga pendidik dan peserta didik telah memiliki pemahaman terkait pembelajaran yang dilakukan, maka penerapan pembelajaran dengan menggunakan aplikasi twitter akan semakin mudah untuk dilaksanakan.

Permasalahan lain yang sangat berpengaruh terhadap penerapan pembelajaran berbasis aplikasi twitter adalah kondisi jaringan yang tidak stabil. Jaringan yang tidak stabil ini dapat disebabkan oleh kondisi tempat tinggal yang tidak memiliki akses jaringan yang baik. Salah satu solusi untuk mengatasi permasalahan ini adalah dengan mencari tempat-tempat yang sekiranya memiliki kondisi jaringan yang stabil. Kemudian, permasalahan lain yang berkaitan dengan jaringan adalah kuota internet yang tidak cukup. Solusi tepat yang dapat digunakan untuk mengatasi permasalahan kuota internet adalah dengan menggunakan wifi. Selain untuk menghemat kuota internet, jaringan pada wifi biasanya juga jauh lebih lancar dan stabil. Dengan demikian, pembelajaran tetap dapat berjalan dengan efektif dan efisien.

\section{Simpulan}

Penerapan pembelajaran berbasis aplikasi merupakan salah satu inovasi yang dapat digunakan untuk meningkatkan kualitas belajar peserta didik. Salah satu aplikasi yang dapat digunakan untuk meningkatkan kualitas belajar peserta didik, terkhusus pada pembelajaran menulis dan membaca cerita pendek adalah aplikasi twitter. Aplikasi twitter merupakan aplikasi yang cukup popular dan banyak digunakan serta dilengkapi berbagai fitur menarik seperti spaces, threads, dan unggahan video. Melalui fitur-fitur ini peserta didik dapat meningkatkan keterampilan menulis dan membaca cerita pendeknya. Dengan twitter, peserta 
didik dapat menulis dengan leluasa tanpa takut tulisannya dicuri orang lain, karena di twitter pengguna lain dapat mengunggah ulang tweet tanpa menghilangkan nama asli si penulis.

Dengan adanya inovasi dalam pembelajaran seperti ini, diharapkan dapat menambah pengetahuan dan pemahaman serta meningkatkan keterampilan menulis dan membaca cerita pendek pada pesera didik. Melalui pembelajaran berbasis aplikasi twitter ini juga diharapkan mampu menarik perhatian peserta didik dan membuat proses pembelajaran lebih efektif, efisien dan menyenangkan. Apabila pembelajaran telah berjalan dengan efektif, efisien, dan menyenangkan, otomatis minat belajar peserta didik juga semakin meningkat sehingga dapat mencapai hasil belajar yang maksimal.

\section{Referensi}

Azeharie, S. (2014). Analisis penggunaan Twitter sebagai media komunikasi selebritis di Jakarta. Jurnal Komunikasi, 6(2), 83-98.

Depdiknas, Undang-Undang Republik Indonesia Nomor 20 Tahun 2003 Tentang Sistem Pendidikan Nasional. 2003, p. 4.

Kholifah, N., Subakti, H., Saputro, A. N. C., Nurtanto, M., Ardiana, D. P. Y., Simarmata, J., \& Chamidah, D. (2021). Inovasi Pendidikan. Yayasan Kita Menulis.

Mustafa, M. N., Hermandra, \& Zulhafizh. (2019). Problem Solving Strategies in Learning Activities: A Study on Students' Perception. In International Seminar and Annual Meeting BKS-PTN Wilayah Barat 2019 (pp. 67-77), Tanjungpinang, Riau.

Mustafa, M. N., Hermandra, \& Zulhafizh. (2019). Teachers' Strategies to Design Media to Implement Communicative Leaning in Public Schools. Journal of Educational Sciences, 3(1), 13-24.

Rahayu, S. M., \& Sutama, S. (2016). Pengelolaan Sarana dan Prasarana Pendidikan Sekolah Menengah Pertama. Jurnal Varidika, 27(2), 123-129.

Samsir, S., Ambiyar, A., Verawardina, U., Edi, F., \& Watrianthos, R. (2021). Analisis Sentimen Pembelajaran Daring Pada Twitter di Masa Pandemi COVID-19 Menggunakan Metode Naïve Bayes. Jurnal Media Informatika Budidarma, 5(1), 157-163.

Sinta, I. M. (2019). Manajemen Sarana dan Prasarana. Jurnal Isema: Islamic Educational Management, 4(1), 77-92.

Zulhafizh, Atmazaki, \& Syahrul, R. (2013). Kontribusi Sikap dan Motivasi Belajar Siswa terhadap Hasil Belajar Bahasa Indonesia. Jurnal Bahasa, Sastra dan Pembelajaran, 1(2), 13-28. 


\section{Data Penulis}

Novi Roza Primadhani, lahir di Pangean, 25 November 2000. Ia merupakan anak bungsu dari lima bersaudara. Pada tahun akademik 2019, ia melanjutkan studi pada strata satu Jurusan Pendidikan Bahasa dan Seni di Program Studi Pendidikan Bahasa dan Sastra Indonesia FKIP Universitas Riau melalui jalur Mandiri (Bina Lingkungan). Menulis merupakan salah satu hal yang cukup ia gemari. Berbagai karya tulis seperti antologi cerpen, antologi pusisi, dan sejenisnya sudah pernah ia terbitkan. Ia juga tergabung dalam Komunitas Menulis Online (KMO) Indonesia sejak tahun 2020. Pada saat ini, ia sedang menjalankan studi di semester 5 dan berharap dapat segera menyelesaikan studi strata satu Jurusan Pendidikan Bahasa dan Seni di Program Studi Pendidikan Bahasa dan Sastra Indonesia FKIP Universitas Riau.

Kontak:

Hp/WA : +6281361221784

Email : noviroza1125@gmai.com 